\title{
HIGHER EDUCATION IN THE FRAMEWORK OF THE BEHAVIORAL ECONOMY OF GENERATION Z IN COLOMBIA
}

\section{EDUCACIÓN SUPERIOR EN EL MARCO DE LA ECONOMÍA DEL COMPORTAMIENTO DE LA GENERACIÓN Z EN COLOMBIA.}

\section{Byron Medina Delgado1}

Wlamyr Palacios Alvarado²

\section{Luis Leonardo Camargo Ariza ${ }^{3}$}

Universidad del Magdalena

\section{RESUMEN}

La economía del comportamiento estudia las dimensiones cognitivas, emocionales y sociales inherentes al obrar del ser humano; sus análisis e investigaciones recientes señalan su importancia en la toma de decisiones 1 Universidad Francisco de Paula Santander, Cúcuta, Colombia. Docente - Investigador Orcid: https://orcid.org/0000-0003-0754-8629 byronmedina@ufps.edu.co

2 Universidad Francisco de Paula Santander, Cúcuta, Colombia. Docente - Investigador Orcid: https://orcid.org/0000-0002-4292-4178 wlamyrpalacios@ufps.edu.co

3 Universidad del Magdalena, Santa Marta, Colombia. Docente - Investigador

Orcid: https://orcid.org/0000-0002-7956-441X

lcamargoa@unimagdalena.edu.co según variables del contexto y características personales del individuo como en el caso de la generación Z; reflexiones que han constituido el tema para el presente artículo cuyo objetivo es explorar las teorías y conceptos sobre la economía del comportamiento y la generación $Z$, con el fin de relacionarlos con la educación superior en materia de identificación de las carreras universitarias de mayor preferencia de parte de esta generación. La metodología aplicada tiene enfoque cualitativo-deductivo y cuantitativo dentro de una investigación exploratoria fundamentada en fuentes secundarias de información, relacionadas con la 
economías del comportamiento, generación Z y áreas del conocimiento con mayor participación en la población de estudiantes universitarios, que analizadas e interpretadas permitieron entender los resultados en cuanto a las áreas del conocimiento de mayor participación en la población de estudiantes universitarios, considerados actualmente como generación $Z$. Como conclusión general, es importante señalar que este enfoque permite sentar las bases para futuras investigaciones, los docentes deben fortalecer sus conocimientos en aplicaciones tecnológicas; así mismo, el comportamiento de la actual generación en materia de elección de una carrera universitaria está relacionado con el interés primordial de lograr una vinculación laboral.

\section{PALABRAS CLAVE:}

Conductual, cognitivo, emocional, social, área del conocimiento

\section{ABSTRACT}

The behavioral economy studies the cognitive, emotional and social dimensions that are inherent to the behavior of the human being, its analysis and recent research indicate its importance in decision-making according to variables of the context and personal characteristics of the individual as in the case of the generation $Z$; reflections that have constituted the subject for this article whose objective is to explore the theories and concepts about behavioral economics and generation $Z$ in order to relate them to higher education in terms of identifying the university careers most preferred by part of this generation. The applied methodology has a qualitative-deductive and quantitative approach within an exploratory research based on secondary sources of information related to behavioral economies, generation $Z$ and areas of knowledge with greater participation in the population of university students, which analyzed and interpreted allowed to understand the results regarding the areas of knowledge with greater participation in the population of university students, currently considered as generation $Z$ and as a general conclusion, it is important to note that this approach allows to lay the foundations for future research, teachers should strengthen their knowledge in technological applications and that the behavior of the current generation in terms of choosing a university career is related to the primary interest of achieving a job relationship.

\section{KEY WORDS}

Behavioral, cognitive, emotional, social, area of knowledge.

\section{INTRODUCTION}

The behaviors of human beings have direct incidence in the social, economic, political and cultural dynamics of nations and regions; therefore, they must be analyzed in economic studies; human activities and their behavior in relation to the Economy are deepened in behavioral economics also called Behavioral Economics.

Within this order of ideas, this article is developed with the objective of exploring the theories and concepts on behavioral economics and Generation $Z$ in order to relate them to Higher Education in terms of identifying the most preferred university careers for this generation. It should be noted that a qualitative-deductive and quantitative methodology is applied, based on exploratory research according to secondary sources of information related to behavioral economics, an approach discussed in the second section, which highlights the importance of human attitudes in economic performance.

The third section analyzes Generation Z, its characteristics and attitudes according to previous research experiences. The fourth section shows the results and discussion, quantifies the population of students in university 
careers according to participation by areas of knowledge and relates the most preferred careers as labor supply from the productive sector, reflections that allow concluding that the attitudes of the new generations and the labor supply from the productive sector significantly influence the choice of a university career.

\section{THEORIZATION}

\subsection{Behavioral economics}

The cognitive, emotional and social dimensions are inherent to human behavior, their analysis and research have given rise to Behavioral Economics, a concept coined by the American Professor of Economics, Richard $\mathrm{H}$. Thaler, who in 2017 was awarded the Nobel Prize in Economics; his contributions have contributed to recent research in this area and especially in economic policy, as pointed out by Maestre (2017).

Within this theoretical framework, behavior that leads to positive results is highlighted, for the benefit of society, humanity and the environment, without losing business objectives. Behavioral Economics and Cognitive Psychology are two sciences that shed light on the factors that impact human decision making and what motivates our behaviors, according to Pfarr (2016).

Born in New Jersey (1945) according to Maestre (2017), Richard H. Thaler is currently a professor at the University of Chicago, director of the Center for Decision Research, co-director of the "Behavioral Economis Project" of the U.S. National Bureau of Economic Research, member of the American Academy of Arts and Sciences and the American Finance Association and the Econometric Society, according to Maestre (2017).

It is worth considering that the topics of behavioral economics are analyzed in some of Thaler's works to understand the main problems of society such as Global Nudge (2008); The Making of Behavorial Economics (2015) and
American Economics Review, Journal of Finance and Journal of Political Economy, among others; his studies highlight the relationships between economic analysis and psychological analysis in human decision-making, affected especially by bounded rationality, social preferences or lack of self-control, factors that make up the so-called behavioral economics.

In this way behavioral economics returns economic thinking to the way it started, with Adam Smith, and continued in the era of Irving Fisher and John Maynard Keynes in the 1930s, according to Thaler (2018), it is so in economic matters Adam Smith (1823-1790) "was far from being the only one of the early economists who had good intuitions about human behavior" (Thaler, 2018, p.12 ) according to Thaler (2018), "Fisher, expounded the first modern economic theory of intertemporal choice, did not think it was a good description of behavior" (p.12) for Keynes, crises arise when investors lower their level, which leads to an increase in unemployment and as a result the level of consumption decreases, according to Aldana (2011).

In the matter of Psychology, behavioral economics retains the idealized model of homoeconomicus, called "Econo" by Thaler (2018, p.12) or humans that affects the rationality of financial markets seeking to characterize the optimal behavior and predict the actual behavior according to Thaler (2018), it is thus that human behavior in the neoclassical economic theory is the pillar of behavioral economics, according to the cited source.

It should be noted that it is required to explain the three most important concepts of behavioral economics, identified by Thaler (2018):

- Overconfidence: there is the presumption that most men have of their own capabilities and adopt an attitude of overestimating their chances of success. 
- Loss aversion: Fear of failure.

- Self-control: Called by Thaler "present bias" (2018, p.13), it underestimates the value in the future and highlights achievement in the present.

It is clear that psychology is a vital factor in political economy as a social science, according to Pareto, cited in Thaler (2018), human nature plays an extremely important role in economic dynamics; people act in different ways, emotional or rational, based on different "biases" or distortion of reality, according to Briceño, Orozco and Galvi, (2018), therefore it is required to understand the reflection of people in a more human way, a concept inherent to behavioral economics, the mental rationalizations of individuals set the tone in a market, given that they are involved in attitudes towards consumption.

Within this framework, it is also vital to highlight Economic Psychology, which analyzes the allocation of initial resources and its influence on decisions, constructs people's judgments and values and, also, their preferences, generating the specific referential states in which attitudes and economic behaviors are manifested, as indicated by Quintanilla (2002), a process that develops in specific socio-economic contexts that have their own legal norms and their own values, according to the cited source.

Finally, it is worth mentioning that the main criticism of behavioral economics is that classical economic analysis has not understood or addressed human behavior in the right way, according to Chico (2019), since it has always assumed a rational and utility-maximizing agent, without taking into account his emotions in the decision-making process, according to Chico (2019).

\subsection{Generation Z}

According to Ohstrategy (2016), cited in De la Hoz, Bejarano, Ortiz and Porras (2019), its main characteristic is to have been born with cell phones at their fingertips, their taste for the immediate now and digital self-knowledge, they look to the future, they are a realistic generation, they work to achieve personal success, according to De Barba (2016), cited in de la Hoz, et. al.

According to the cited source, the vast majority of students of this generation have graduated from high school or are finishing it, before finishing their high school cycle they begin to think about pursuing a university career in a higher education institution, Generation Z students consider certain aspects such as: public or private higher education institution, type of career, distance or classroom mode, duration time, among others, in order to choose properly and thus project themselves to achieve an adequate future for their personal and professional life, as stated by de la Hoz, et. al, (2019).

It is added to the above that these young people do not contemplate the professional life project according to Alejos and Sandoval (2010) cited in De la Hoz, et. al., (2019). Essentially, from the socio-cognitive point of view, the Generation Z student is characterized by some differentiating features with respect to those of previous generations, according to Pérez-Escoda; Castro-Zubizarreta; Fandos-Igado, (2016); they possess rapid response capacity, their desire for immediacy and continuous interaction, are characteristics of Generation Z. Other authors such as Fernández and Fernández (2016), cited in Pérez-Escoda et. al. (2016), point out that Generation Z students conceive themselves as experts and competent in ICT, show a high commitment to technology, where learning is usually independent or self-taught, another characteristic of this generation is the preference for visual information and easy development in digital and visual environments managing several tasks at the same time.

In accordance with the above, it is noteworthy that the next important generation for universities is Generation Z, the so-called Screenagers ("Screen Teens"), according to Silvestre and 
Cruz (2016), have been shaped by technology and feel comfortable sharing their experiences online, are selfish, with high self-esteem, according to the cited source; is a digital and critical generation that delays adulthood, buys online and prioritizes sustainability, sociologists describe them as spoiled, selfish, impatient, adapt to changes and prefer a job that generates satisfaction, as noted by Silvestre and Cruz (2016).

With the above, the demand for the development of basic skills in compulsory education, especially digital competence, is a requirement that teachers must accredit to facilitate generational change and adaptation to new social skills that have to do with the use of technologies and the needs of new learning for a changing society, according to Fernández-Cruz and FernándezDíaz (2016); it is thus important to examine the preparation of current teachers to lead the teaching-learning processes of Generation Z students, according to the cited source.

In this order of ideas, it is important to mention that currently the first members of Generation $Z$ are at a stage either about to finish their university life or already looking for a job, while the younger ones are in the dilemma of choosing a career to study, according to QuestionPro (s.f.), their characteristic is a very entrepreneurial generation and a percentage of them believe that they do not necessarily have to study to reach professional success, according to the cited source.

\section{METHODOLOGY}

The objective of this article is to examine the theories on behavioral economics and Generation $Z$, based on the exploration of secondary sources of information with the purpose of familiarizing researchers with the topics of interest; thus, with qualitative criteria the document is developed, given that "qualitative approaches are focused on deepening the phenomena by exploring them from the perspective of the participants"
(Hernández et al., 2014, p.376).

In other words, according to Báez (2014) the qualitative approach "entails, methodologically, adopting a research attitude that seeks knowledge and understanding of a phenomenon (the qualitative research method) without prejudging what we are going to find and without the requirement of reaching statistically verifiable results" (Báez, 2014, p.27).

It should be noted that the article employs the deductive criterion, considering that it is related to the "process of knowledge that begins with the observation of general phenomena with the purpose of pointing out the particular truths contained explicitly in the general situation" (Méndez, 2007, p.236 ); in addition, since it is an innovative topic, the type of exploratory research is applied, at a first level of knowledge, to achieve a first approach to the problem to be studied and known; given that exploratory studies "are used when the objective is to examine a little studied or novel topic" (Hernández et al., 2014, p.91).

The above process involved the search, selection, organization, analysis and interpretation of the information identified and collected based on secondary sources of information referenced in the citations and bibliography of the document.

\section{RESULTS AND DISCUSSION}

Previous experiences indicate that the decision to start university studies on the part of the current generation involves a search and selection process where students prioritize certain reasons for choosing studies that respond to their own assessments and motivations and to external factors such as family expectations or social stereotypes, according to Abarca, Gormaz, and Leiva (2012). cited in De la Hoz, et. al. (2019).

In this sense, the results showed that the preferences of young people are the determining factor at the time of choosing their career, with variations by locality and social stratum, so that they prefer the satisfaction generated by 
performing a task they like, before various external factors such as generating benefits to the community, the salary they will earn, or family influence, as stated by de la Hoz, et. al. (2019).

According to the cited source, the growth of the informal sector is a problem that must be faced, given that it has an impact on the unemployment of professionals; according to a study called "Labor Trends Report" of 2018, cited in de la Hoz, et. al. (2019), concluded that the majority of unemployed are business administrators, followed by industrial engineers, accountants, economists, business administrators, psychologists, publicists and journalists; it is evident that the deterioration of the labor market in Colombia is strengthening the informal sector.

The characteristics of young people of this century to fulfill their goals and proposed projects are linked to interest, aptitude, gender, and self-sufficiency, but also to other factors such as contextual environment, which is the socioeconomic level that is present is the choice of professional career, in the process of choice the presence of the counselor, but is also influenced by family and friends who generate a closer bond with young people and guide them in decisions and tastes. according to De la Hoz, et. al. (2019).

Quantitatively, the results in the following table show the participation of the areas of knowledge in the total population of students in higher education in Colombia.

From Table 1, it can be seen that the greatest participation is in Economics, Administration and Accounting, since they are the ones with the greatest participation in the labor demand of the productive sector.

Table 1. Participation by area of knowledge in total enrollment.

\begin{tabular}{|l|c|c|}
\hline \multicolumn{1}{|c|}{ Area of knowledge } & Participation & Total students \\
\hline Economics, administration, accounting and related areas. & $32,62 \%$ & 785.503 \\
\hline $\begin{array}{l}\text { Engineering, architecture, urban planning and related } \\
\text { areas. }\end{array}$ & $28,00 \%$ & 674.251 \\
\hline Social and human sciences. & $17,00 \%$ & 409.367 \\
\hline Education sciences. & $8,44 \%$ & 203.239 \\
\hline Health sciences. & $6,80 \%$ & 163.747 \\
\hline Arts. & $3,27 \%$ & 78.743 \\
\hline Mathematics and natural sciences. & $1,97 \%$ & 47.438 \\
\hline Agronomy, veterinary and related sciences. & $1,90 \%$ & 45.753 \\
\hline Total & $\mathbf{1 0 0 , 0 0 \%}$ & $\mathbf{2 . 4 0 8 . 0 4 1 *}$ \\
\hline
\end{tabular}

Sources: Own design based on Ministry of National Education, Sistema Nacional de Información de la Educación Superior - SNIES (2017).

Thisissummarized in Figure 1, wherethedemand for highly specialized professionals continues to increase. Sectors such as commerce and construction are booming in the Colombian market, although the financial industry is the one that employs more professionals. Specifically, according to Universia (2020) these are the careers that receive the most job offers: business administration; industrial engineering; systems engineering; accounting; business administration; economics; electronic engineering; financial management; and telecommunications engineering, according to universia (2020). 
Figure 1. Student population by knowledge area 2019

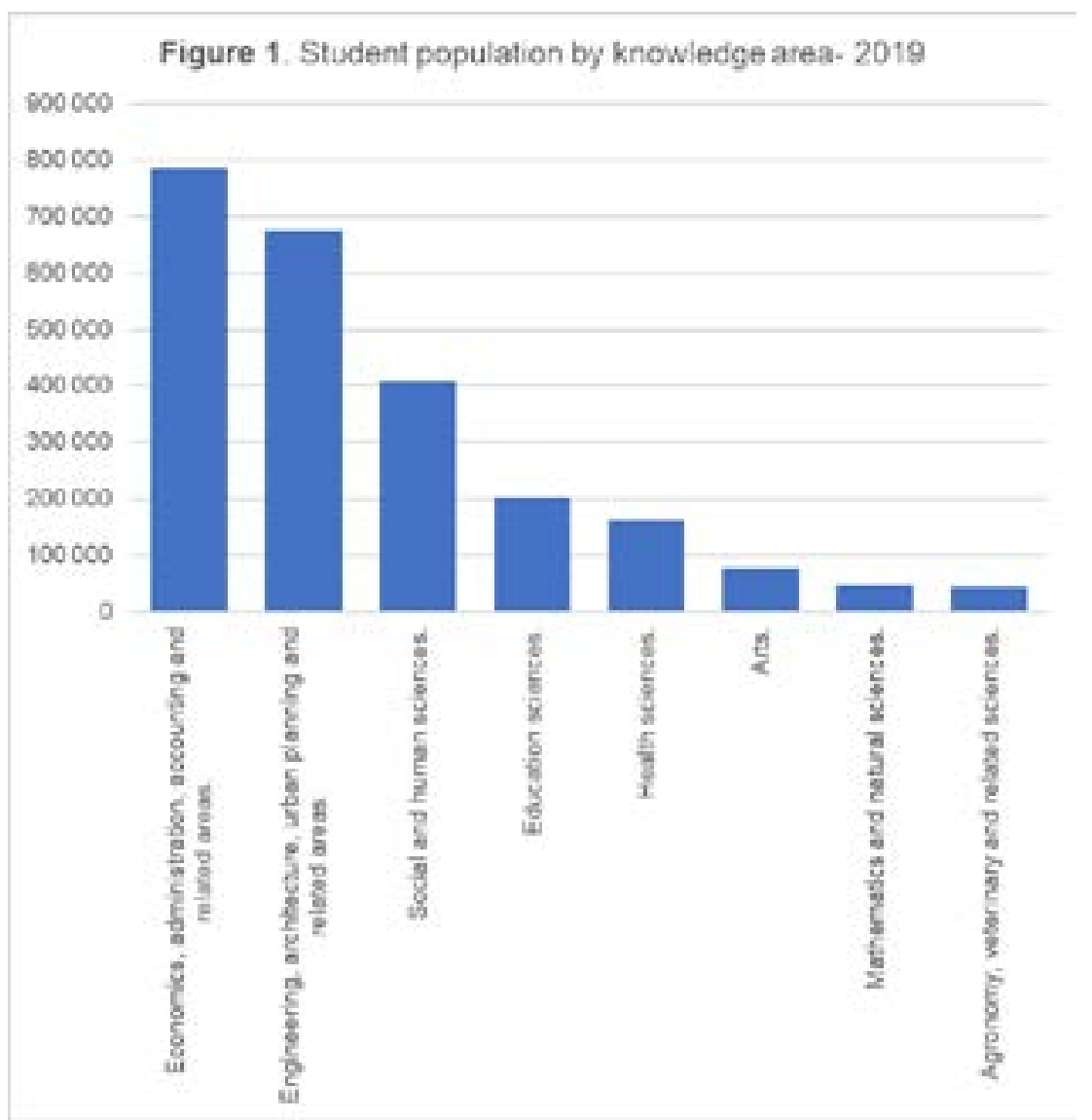

\section{CONCLUSIONS}

The behavioral economics approach is new and rapidly multiplying, which gives rise to other research in this area relating the cognitive and social behavior of students to areas of knowledge.

Within this context of behavioral economics, psychology and human behavioral sciences acquire considerable importance.

The study of psychological and economic factors helps to better understand the educational reality in higher education institutions and to improve the thematic content in each area of knowledge.

Behavioral economics should be considered as a type of cutting-edge discipline that should be studied with the support of statistical databases of educational institutions.
It is important to point out that there are still questions regarding behavioral economics that should be gradually clarified through research in different contexts.

Behavioral economics, with its interdisciplinary characteristic, is an organized discipline that links classical economics with cognitive psychology and its diversity of approaches.

Cognitive and emotional factors that influence the decisions of individuals, social groups, organizations and educational institutions are becoming increasingly important.

Universities should study in depth the current generation of students, called Generation Z, in terms of their specific characteristics and lifestyles.

In addition, study in this generation their family relationships, recreational activities, use of 
technology for learning and the most preferred means of communication.

The training of teachers in the application of ICTs to the teaching-learning process is a factor that contributes to the improvement of the competencies of current teachers in educational institutions.

Previous experiences indicate that the current generation called $Z$, when deciding to start university studies, prioritize certain reasons for choosing studies that respond to their own assessments and motivations and to external factors such as family expectations or social stereotypes.

The results of research carried out showed that the preferences of young people are the determining factor at the time of choosing their career, which vary according to location and social class, so that they prefer the satisfaction generated by performing a task that they like, before various external factors such as generating benefits to the community, the salary they will earn, or family influence.

The current generation has characteristics related to the fulfillment of their goals and proposed projects, which are linked to interest, aptitude, gender, and personal self-sufficiency, but also to other external factors such as the context, socioeconomic level, the presence of the counselor, family influence and friends.

The areas of knowledge identified are Economics, Administration, Accounting and related areas, Engineering, Architecture, Urban Planning and related areas, Social and Human Sciences, Education Sciences, Health Sciences, Fine Arts, Mathematics and Natural Sciences, Agronomy, Veterinary and related areas.

According to the area of knowledge, the greatest participation is in Economics, Administration and Accounting by students, which in turn are the ones with the greatest participation in labor demand by the productive sector.
As a general conclusion, the behavior of the current generation in terms of the choice of a university career is related to the primary interest of achieving a labor link.

\section{BIBLIOGRAPHIC REFERENCES}

Báez y Pérez de Tudela, Juan, (2014), El método cualitativo de investigación desde la perspectiva de marketing: el caso de las universidades públicas de Madrid, Universidad Complutense de Madrid Facultad de Ciencias Económicas y Empresariales Departamento de Comercialización e Investigación de Mercados, Tesis Doctoral Madrid.

Briceño, Bertha, Orozco, Arianna y Galvi, Marcela, (2018), Economía del comportamiento: aprende sobre sus conceptos básicos y aplicaciones, División de Gestión de Conocimiento del Banco Interamericano de Desarrollo disponible en https:// blogs.iadb.org/conocimiento-abierto/es/ economia-del-comportamiento/

Chico Téllez, Paola, (2019), Economía del Comportamiento, Facultad de Ciencias Económicas y Empresariales, Universidad de Valladolid, España.

Conferencia de la Naciones Unidas sobre Comercio y Desarrollo UNCTAD (2010) Economía Creativa, Una Opción factible de desarrollo.

De La Hoz Carracedo Edwin, Bejarano Cárdenas Johana Andrea, Ortiz Isaza Natalia y Porras Castro Sandra Milena, (2019), Preferencias para la elección de Carreras Universitarias en la Generación $Z$, Institución Universitaria Politécnico Grancolombiano, Facultad de Sociedad, Cultura y Creatividad, Grupo de Investigación de Psicología, Educación de Cultura, Escuela de Psicología, Talento 
Humano y Sociedad Gestión Educativa, Bogotá D.C.

El Tiempo (2020), Matrículas en universidades, a la baja desde antes de la pandemia, disponible en https://www.eltiempo. com/vida/educacion/informerevela-disminucion-de-estudiantesmatriculados-en-universidades-decolombia-526992.

Fernández-Cruz, Francisco-José; FernándezDíaz, Ma-José, (2016), Los docentes de la Generación Z y sus competencias digitales Comunicar, vol. XXIV, núm. 46, pp. 97-105 Grupo Comunicar Huelva, España.

Hernández Sampieri, R., Fernández Collado, C., Baptista Lucio, M., (2014), Metodología de la Investigación, Sexta Edición, Mcgraw-Hill / Interamericana Editores, S.A., México.

La República, (2019), Conozca cómo funciona la economía del comportamiento en su bolsillo, disponible en https://www. larepublica.co/finanzas/como-funcionala-economia-del-comportamiento-en-subolsillo-2885447

Maestre, Raúl Jaime, (2017), Richard H. Thaler, premio Nobel de Economía 2017, Foro Económico Mundial, disponible en https://es.weforum.org/agenda/2017/10/ richard-h-thaler-premio-nobel-deeconomia-2017/

Méndez, Carlos, (2007), Metodología, Diseño y desarrollo del proceso de investigación con énfasis en ciencias empresariales, $4^{\circ}$ edición, Editorial Limusa, Bogotá D.C.

Ministerio de Educación Nacional, MinEducación, (2017), Avances en la cobertura en educación superior en Colombia, Educación Superior, Boletín No. 1, disponible en https://snies.mineducacion. gov.co/1778/articles-393225_boletin dic_2017.pdf

Morales Valiente, Claudia, (2017), La creatividad, una revisión científica Arquitectura y Urbanismo, vol. XXXVIII, núm. 2, pp. 53-62 Instituto Superior Politécnico José Antonio Echeverría Ciudad de La Habana, Cuba.

Muñoz, Ana María, Borbón, Carlos Gabriel, Laborín, Jesús Francisco, (2019). Economía del Comportamiento: un campo fértil para la investigación de aplicaciones en política pública para México, Estudios sociales. Revista de alimentación contemporánea y desarrollo regional, vol. 29, núm. 53, México.

Organización de las Naciones Unidas para la Educación, la Ciencia y la Cultura, Unesco, (2018), Colombia: invertir en la creatividad, disponible en https:// es.unesco.org/creativity/news/colombiainvertir-en-creatividad

Pérez-Escoda, Ana; Castro-Zubizarreta, Ana; Fandos-Igado, Manuel, (2016), La competencia digital de la Generación Z: claves para su introducción curricular en la Educación Primaria Comunicar, vol. XXIV, núm. 49, octubre-diciembre, 2016, pp. 71-79 Grupo Comunicar Huelva, España.

Pfarr, Nikki, (2016), Aplicando la Economía del Comportamiento y la Psicología Cognitiva al Proceso de Diseño, Capítulo 2, Guía de Economía del Comportamiento Volumen 1: Políticas Públicas Instituto Mexicano de Economía del Comportamiento, disponible en https://www.bi.team/wpcontent/uploads/2016/09/v9-imec-vol-1-1. pdf. 
QuestionPro, (s.f.), Generación Z: Todo lo que necesitas saber de ellos, disponible en https://www.questionpro.com/blog/es/ generacion-zl

Quintanilla, Ismael, (2002), Daniel Kahneman y la Psicología Económica, Revista de Psicología del Trabajo y de las Organizaciones, vol. 18, núm. 1, pp. 95108 Colegio Oficial de Psicólogos de Madrid, Madrid, España.

Silvestre, Emmanuel; Cruz, Oliver, (2016), Conociendo la próxima generación de estudiantes universitarios dominicanos a través de las redes sociales, Ciencia y Sociedad, vol. 41, núm. 3, pp. 475-503 Instituto Tecnológico de Santo Domingo Santo Domingo, República Dominicana.

Thaler, Richard H., (2018), Economía del comportamiento: pasado, presente $y$ futuro. Universidad de Chicago, USA.

Universia, (2020), Las 10 carreras con más salidas laborales de Colombia, disponible en https://www.universia. net/co/actualidad/orientacionacademica/10-carreras-mas-salidaslaborales-colombia-1157484.html

Villa, J., Rojas, M. y Coronado, L. (2017). Emprendimiento basado en pensamiento lateral: Aplicación mediante un juego. EnContexto, 5(6), 117-135.

Yentzen, Eduardo, (2003), Teoría general de la creatividad Polis, Revista de la Universidad Bolivariana, vol. 2, núm. 6, 2003, p. 0 Universidad de Los Lagos Santiago, Chile. 